\title{
Respon Pertumbuhan Anggrek Dendrobium Terhadap Jenis Media Tanam Dan Pupuk Daun
}

\section{Respon Pertumbuhan Anggrek Dendrobium Terhadap Jenis Media Tanam Dan Pupuk Daun}

\author{
Tri Dewi Andalasari, Yafisham, dan Nuraini \\ Fakultas Pertanian Universitas Lampung \\ email: tridewiandalasari@ymail.com
}

\begin{abstract}
The use of ferns as growing media orchids ranging deemed expensive, so it is necessary to find an alternative media as a media surrogate fern that has been used.This study aimed to explore alternative growing media and fertilizers are good for growth and development of dendrobium orchids . Selection of a good planting medium and the proper use of fertilizers can be expected to support healthy plant growth and quality of orchids

.Greenhouse experiments were conducted at the Faculty of Agriculture University of Lampung. Treatment arrangement was factorial by randomized complete block design with three replication. The treatment is done byp factorial ( $6 \times 2$ ). The first factor is the type of growing medium consists of wood charcoal (M1), ferns ( M2), husk + sawdust ( M3 ), acacia bark (M4), cocochip (M5) and coconut bark (M6). The second factor is the type of foliar fertilizer consists of Gandasil ( P1 ) and Hyponex ( P2 ). Data were analyzed by analysis of variance followed by HSD test at 5\% level.The results showed that the use of media orchids ferns produce good vegetative growth, not unlike the use of planting medium charcoal, charcoal husk + sawdust, bark and bark acacia tree oil, but it is different than the use of cocochip shown in variable plant height, number of leaves, leaf length and leaf width. While foliar fertilizers that produce good growth is fertilizer Gandasil .
\end{abstract}

Key word: dendrobium, growing media, foliar fertilizers

Diterima: 01-01-2014, disetujui:17-01-2014

\section{PENDAHULUAN}

Dendrobium merupakan salah satu anggrek yang berpotensi untuk terus dikembangkan karena memiliki beragam jenis bentuk, warna dan ukurannya. Selain itu anggrek dendrobium juga dapat dijadikan sebagai bunga potong maupun sebagai bunga pot. Produksi anggrek potong tahun 2007 menduduki urutan ke 5 setelah gladiol yaitu sebanyak 9.484.393 (Direktorat Jenderal Hortikultura 2003-2007).

Dendrobium adalah anggrek yang bersifat epifit, yang hidupnya menempel pada batang, dahan, atau ranting pohon yang sudah mati (Sutiyoso dan Sarwono, 2003), akarnya sebagian 

menempel pada medianya sebagian menjuntai bebas di udara (Sandra 2001). Anggrek juga dapat menempel pada pohon yang masih hidup tanpa mengganggu pertumbuhan inangnya. Fungsi utama media tanam anggrek terutama untuk menopang tegaknya tanaman sehingga suplai hara yang utama diberikan melalui daun.

Menurut Iswanto, (2002) media tanam yang baik harus memenuhi kreteria antara lain; tidak mudah lapuk, tidak mudah menjadi sumber penyakit, aerasi baik, mampu mengikat air dan unsur hara dengan baik (Gunawan, 2000), mudah didapat dan harga relative murah. Media tumbuh yang baik bagi anggrek (famili Orchidaceae) harus memenuhi beberapa persyaratan, antara lain tidak lekas melapuk dan terdekomposisi, tidak menjadi sumber penyakit, mempunyai aerasi dan draenase yang baik, mampu mengikat air dan zat-zat hara secara optimal, dapat mempertahankan kelembaban di sekitar akar, dibutuhkan ph media 5-6, ramah lingkungan serta mudah didapat dan relatif murah harganya. Media tumbuh tanaman anggrek yang umum digunakan adalah arang, pakis, moss, potongan kayu, potongan bata atau genting, serutan kayu, kulit pinus dan serabut kelapa ( Benamehuli Ginting, 2008). KP Penelitian Tanaman Hias, Deptan Dimuat pada surat kabar Sinar Tani, 7 - 13 Mei 2008

Pakis merupakan media tanam yang umum digunakan dalam budidaya anggrek, namun permintaan pakis yang semakin banyak akan meningkatkan harga jual dan penggadaan pakis menjadi terbatas. Salah satu usaha untuk mengatasi hal tersebut adalah dengan mencari alternative media tanam yang baik digunakan untuk pertumbuhan anggrek. Media alternative yang dicobakan dalam penelitian ini adalah: arang kayu, serbuk gergaji + sekam, kulit pohon akasia, cocochip, dan kulit batang kelapa.

Arang kayu memiliki beberapa kelebihan diantaranya mudah menyerap air, tidak mudah ditumbuhi cendawan, murah dan mudah didapat, dapat bertahan hingga dua tahun, tetapi miskin unsur hara (Supari, 1999).

Arang sekam adalah limbah penggilingan padi merupakan jenis media tanam yang banyak tersedia, sehingga mudah didapat dan murah harganya, selain itu kelebihan arang sekan yang lain adalah steril karena sudah melalui proses pembakaran.

Cocochip juga merupakan limbah kelapa berupa sabut kelapa yang dipotong kecil. Sabut kelapa juga cukup mudah didapat dan murah harganya, sehingga berpotensi untuk digunakan sebagai alternatif media tanam anggrek.

Kulit batang akasia dan batang kelapa juga merupakan limbah dari pengolahan kayu. Selama ini kulit kedua batang tersebut tidak digunakan, tetapi memiliki potensi untuk digunakan sebagai media tanam anggrek.

Lingga (2001) pupuk daun termasuk pupuk buatan yang cara pemberiannya melalui penyemprotan ke daun. Pupuk yang disemprotkan melalui daun akan masuk melalui stomata secara difusi dan selanjutnya akan masuk ke dalam sel-sel kloroplas baik yang di dalam sel penjaga, mesofil daun, maupun seludang pembuluh dan akan berperan dalam fotosintesis (Agustina, 2004).

Pupuk daun Gandasil memiliki kandungan unsur hara N (20\%), P (15\%), K (15\%) serta tambahan unsur mikro Mg, Mn, B, Cu, Co, dan Zn. Hyponek mengandung N (20 \%), P (20 \%), K (29 $\%)$ serta tambahan unsur mikro (Iswanto, 2002). Penyemprotan anggrek sianjurkan dilakukan pada sore hari karena anggrek termasuk dalam golongan CAM (metabolisme asam crasulace), sifat stomata membuka pada malam hari dan menutup pada siang hari. Mekanisme CAM dalam mengikat karbondioksida pada malam hari ketika stomata membuka, kesempatan ini pula digunakan agar air dan unsur hara dapat masuk ke dalam stomata. Dengan demikian tumbuhan CAM dapat berfotosintesis tanpa kehilangan sejumlah besar air karena transpirasi stomata. (Salisbury dan Ross, 1992), karena 
itulah tanaman anggrek termasuk tanaman yang cukup tahan terhadap kekeringan, setidaknya dapat bertahan hidup sementara tanaman lain sudah mati. Penyemprotan anggrek diberikan baik melalui daun maupun ke media tanam, karena anggrek termasuk tanaman epiphyt yang utamanya menempel pada media tanam. Selain itu media tanam yang digunakan merupakan media tanam yang miskin unsur hara.

Tujuan penelitian adalah mendapatkan media tanam yang dapat digunakan sebagai alternatif pengganti media pakis dan mengetahui jenis pupuk yang dapat meningkatkan pertumbuhan anggrek dendroboium.

\section{METODE}

Penelitian dilakukan di Rumah Kaca Fakultas Pertanian Universitas Lampung. Bahan yang digunakan: Anggrek dendrobium yang digunakan berumur 8 bulan dari bibit botol, pot berdiameter $15 \mathrm{~cm}$ berbahan gerabah dengan tinggi $10 \mathrm{~cm}$, arang kayu, pakis, arang sekam, serbuk gergaji kayu sengon, kulit batang akasia, potongan sabut kelapa (cocochip), kulit batang kelapa. Pupuk Gandasil dan Hyponex. Pestisida untuk mencegah serangan jamur dan hama pengganggu.

Percobaan disusun secara faktorial $6 \times 2$. Faktor pertama adalah jenis media tanam : arang kayu (M1), pakis (M2), serbuk gergaji + sekam (M3), kulit batang akasia (M4), cocochip (M5), dan kulit batang kelapa (M6). Faktor kedua adalah jenis pupuk Gandasil (P1), dan Hyponex (P2). data diolah dengan sidik ragam dan dilanjutkan dengan uji BNJ pada taraf $5 \%$.

Sebelum digunakan media tanam direndam dengan pestisida (fungisida dan insektisida) sesuai anjuran selama satu malam. Bibit anggrek ditanam pada pot yang berisi media sesuai dengan perlakuan. Media diberikan sampai ketinggian $1 \mathrm{~cm}$ dari bibir pot.

Pupuk daun diaplikasikan pada pagi hari dengan harapan stomata masih membuka. Konsentrasi pupuk daun diberikan adalah 2 g/l. Penyemprotan dilakukan seminggu sekali dengan volume semprot sebanyak $10 \mathrm{ml}$ per tanaman. Sampai bulan ke lima penyemprotan menggunakan pupuk daun untuk pertumbuhan vegetatif, setelah bulan ke enam dilanjutkan dengan pupuk untuk pertumbuhan generatif.

Parameter yang diamati antara lain tinggi tanaman, jumlah daun, panjang daun, lebar daun, dan jumlah anakan. Pengamatan dilakukan pada saat awal tanam dan akhir penelitian (sampai tanaman berbunga)

\section{HASIL DAN PEMBAHASAN}

Secara umum hasil penelitian terhadap anggrek dendrobium menunjukkan pertumbuhan yang baik. Hasil pengamatan menunjukkan bahwa keenam jenis media tanam memberikan pengaruh yang nyata terhadap tinggi tanaman, jumlah daun, panjang daun, dan lebar daun, tetapi tidak mempengaruhi jumlah anakan. Kedua jenis pupuk daun yang digunakan berpengaruh nyata terhadap tinggi tanaman, dan lebar daun, tetapi tidak mempengaruhi jumlah daun, panjang daun dan jumlah anakan. Respon pertumbuhan anggrek terhadap media tanam tidak tergantung pada jenis pupuk yang diberikan. Perbedaan pertumbuhan karena pengaruh perlakuan jenis pupuk ditunjukkan dengan nilai tengah pada Tabel 1. 
Tri Dewi Andalasari, Yafisham, dan Nuraini: Respon Pertumbuhan Anggrek Dendrobium ...

Tabel 1. Pengaruh jenis pupuk terhadap tinggi tanaman $(\mathrm{cm})$, jumlah daun, panjang daun $(\mathrm{cm})$, lebar daun $(\mathrm{cm})$ dan jumlah anakan.

\begin{tabular}{lcccccc}
\hline \multirow{2}{*}{ Perlakuan } & \multicolumn{5}{c}{ Nilai tengah } \\
\cline { 3 - 6 } \multicolumn{2}{c}{} & $\begin{array}{c}\text { Tinggi } \\
\text { tanaman(cm) }\end{array}$ & Jumlah daun & $\begin{array}{c}\text { Panjang } \\
\text { daun(cm) }\end{array}$ & $\begin{array}{c}\text { Lebar } \\
\text { daun(cm) }\end{array}$ & $\begin{array}{c}\text { Jumlah } \\
\text { anakan }\end{array}$ \\
\hline Gandasil & (P1) & $24,39 \mathrm{a}$ & $15,90 \mathrm{a}$ & $14,40 \mathrm{a}$ & $3,81 \mathrm{a}$ & $3,83 \mathrm{a}$ \\
Hyponex & (P2) & $19,32 \mathrm{~b}$ & $15,31 \mathrm{a}$ & $14,04 \mathrm{a}$ & $3,32 \mathrm{~b}$ & $3,69 \mathrm{a}$ \\
BNJ P & 1,39 & 1,90 & 0,81 & 0,22 & 0,41 \\
\hline
\end{tabular}

Keterangan: Nilai tengan yang diikuti oleh huruf yang sama dinyatakan tidak berbeda menurut uji BNJ pada taraf 5\%.

Sedangkan pengaruh perlakuan media tanam terhadap pertumbuhan ditunjukan dengan nilai tengah pada tabel 2 .

Tabel 2. Pengaruh media tanam terhadap tinggi tanaman $(\mathrm{cm})$, jumlah daun, panjang daun $(\mathrm{cm})$, lebar daun $(\mathrm{cm})$ dan jumlah anakan.

\begin{tabular}{lcccccc}
\hline \multirow{2}{*}{\multicolumn{2}{c}{ Perlakuan }} & \multicolumn{5}{c}{ Nilai tengah } \\
\cline { 2 - 6 } & \multicolumn{2}{c}{$\begin{array}{c}\text { Tinggi } \\
\text { tanaman(cm) }\end{array}$} & Jumlah daun & $\begin{array}{c}\text { Panjang } \\
\text { daun(cm) }\end{array}$ & $\begin{array}{c}\text { Lebar } \\
\text { daun(cm) }\end{array}$ & $\begin{array}{c}\text { Jumlah } \\
\text { anakan }\end{array}$ \\
\hline \multicolumn{2}{l}{ Arangkayu(M1) } & $22,34 \mathrm{ab}$ & $16,63 \mathrm{ab}$ & $13,59 \mathrm{~b}$ & $3,75 \mathrm{ab}$ & $3,75 \mathrm{a}$ \\
Pakis & (M2) & $24,02 \mathrm{a}$ & $18,81 \mathrm{a}$ & $15,22 \mathrm{a}$ & $3,83 \mathrm{a}$ & $3,94 \mathrm{a}$ \\
AS+SG & (M3) & $22,24 \mathrm{ab}$ & $15,31 \mathrm{ab}$ & $14,39 \mathrm{ab}$ & $3,50 \mathrm{ab}$ & $3,69 \mathrm{a}$ \\
Akasia & (M4) & $21,69 \mathrm{ab}$ & $15,63 \mathrm{ab}$ & $14,73 \mathrm{ab}$ & $3,37 \mathrm{ab}$ & $3,56 \mathrm{a}$ \\
Cocochip (M5) & $19,75 \mathrm{~b}$ & $13,13 \mathrm{~b}$ & $12,51 \mathrm{~b}$ & $3,18 \mathrm{~b}$ & $4,06 \mathrm{a}$ \\
\multicolumn{2}{l}{ Kelapa (M6) } & $21,07 \mathrm{ab}$ & $14,13 \mathrm{ab}$ & $13,86 \mathrm{ab}$ & $3,79 \mathrm{ab}$ & $3,56 \mathrm{a}$ \\
\multicolumn{2}{c}{ BNJ M } & 3,58 & 4,89 & 2,09 & 0,58 & \\
\hline
\end{tabular}

Keterangan: Nilai tengan yang diikuti oleh huruf yang sama dinyatakan tidak berbeda menurut uji BNJ pada taraf $5 \%$.

Penggunaan media tanam pakis ternyata menghasilkan pertumbuhan yang tidak berbeda dibandingkan kelima jenis media tanam lainnya, ditunjukkan dengan variabel tinggi tanaman, jumlah daun, lebar daun, panjang daun, tetapi tidak berbeda pengaruhnya pada jumlah anakan anggrek, sedangkan penggunaan cocochip menghasilkan pertumbuhan anggrek yang paling rendah. Hasil yang sama juga ditunjukkan oleh penelitian Santina (1990) terhadap anggrek dendrobium dimana media tanam terbaik adalah media tanam pakis yang ditunjukkan pada variabel tinggi tanaman dan panjang daun. Berbeda dengan hasil penelitian Sri Wardani, Hot Setiado, dan Syarifuddin Ilyas (2013), media yang terbaik dalam tahap aklimatisasi pada anggrek adalah cocopeat yang memiliki kemampuan menyimpan air dan hara dengan baik. Keunggulan media tersebut dapat dilihat dari saat muncul tunas dan jumlah tunas.

Keunggulan media pakis dibandingkan dengan media tanam yang lain diduga media pakis memiliki kreteria yang baik bagi pertumbuhan tanaman anggrek diantaranya pakis mampu mengikat dan menyimpan air dengan baik, memiliki aerasi dan draenasi baik, melapuk secara perlahan dan mengandung unsur hara yang diperlukan bagi tanaman anggrek (Widiastoety, 2004). Kemampuan pakis dalam mengikat dan menyerap air mengakibatkan pakis mudah menyerap cairan pupuk yang disemprotkan dan dapat menambah kandungan unsur hara yang ada pada media dan dapat membantu mempercepat pertumbuhan anggrek. Selain itu menurut Don, Emir, dan Hadibroto (2001), pakis memiliki kandungan gula, asam amino, asam alifatik dan konsituen ester yang dibutuhkan anggrek. 
Media tanam pakis juga memiliki kelebihan yaitu tidak mudah lapuk sehingga tanaman dapat menyerap unsur hara yang dikandungnya dalam kurun waktu yang lama.

Respon pertumbuhan yang ditunjukkan pada tinggi tanaman, jumlah daun, panjang daun dan lebar daun paling rendah terdapat pada media tanam cocochip. Beberapa faktor yang diduga menjadi penyebab rendahnya respon pertumbuhan tanaman anggrek terhadap media tanam diantaranya adalah cocochip merupakan media tanam yang terlalu ringan dan mudah lapuk. Media tumbuh tanaman anggrek selain sebagai penyedia air dan unsur hara juga sebagai tempat melekatnya akar dan tempat berdirinya tanaman Widiastoety (2004). Tanaman anggrek yang ditanam pada media cocochip tidak mampu berdiri tegak meskipun diberi penopang dan akar yang tumbuh tidak dapat melekat dengan baik pada media tanam, padahal dengan berdiri tegak tanaman dapat memanfaatkan cahaya matahari dan udara dengan lebih banyak.

Penggunaan kulit batang akasia memberikan respon pertumbuhan yang cukup baik karena kulit batang akasia bertektur kasar dan cukup keras sehingga akar anggrek mudah melekat dan dapat memegang air dengan baik serta memiliki aerasi yang baik. John dan Bowyer (1986) menyatakan bahwa kulit batang akasia mengandung lignin dan polisakarida. Diharapkan bahan ini jika melapuk akan terurai menjadi bahan yang lebih sederhana dan dapat menambah unsur hara. Hasil penelitian lain menunjukkan bahwa pengunaan berbagai jenis media lumut, sabut kelapa, cacahan pakis, arang sekam padi, akar kadaka) dan kulit kayu trembesi berpengaruh tidak nyata terhadap pertambahan tinggi tanaman $(\mathrm{cm})$, persentase tanaman hidup, pertambahan jumlah daun (helai), jumlah anakan/tanaman, dan pertambahan jumlah akar (helai) pada aklimatisasi anggrek Dendrobium $s p$ (hibrida) (Tangti Yosepa, Chairani Siregar, Evi Gusmayanti, 2013).

Hasil penelitian pada pertumbuhan anggrek kultivar Dendrobium Jayakarta menunjukkan bahwa media sabut kelapa pot; media campuran arang dan sabut kelapa; media campuran arang dan batu marus memberikan hasil yang lebih baik dibanding media lainnya. Jenis media rockwool, batu apung, batu marus dan batu split dapat digunakan sebagai media tanam anggrek, namun perlu dicampur dengan arang, (Ginting B., W. Prasetio dan T. Sutater, 2004)

Pemberian pupuk yang berbeda memberikan respon pertumbuhan yang berbeda pula terutama pada veriabel tinggi tanaman, jumlah daun, dan lebar daun. Pemberian pupuk Gandasil menghasilkan respon pertumbuhan yang lebih baik dibandingkan Hyponex, hal ini diduga karena kandungan unsur hara pada kedua jenis pupuk yang berbeda. Gandasil mengandung N 20\%, P 15 \%, K 15\% dan Mg 1 $\%$ dan tambahan unsur mikro $\mathrm{Mn}, \mathrm{B}, \mathrm{Cu}, \mathrm{Co}, \mathrm{Zn}$ serta adanya vitamin untuk pertumbuhan tanaman seperti aneurin, laktoflavin, nicotinic acid amide (PT Kalatham), sedangkan pupuk Hyponex mengandung N 20\%, P 20\%, K 20\% dan tambahan unsur mikro B, Ca, Co, Cu, Fe, Mg, Mn, Mo,S dan Zn (PT Paramanira).

Pada fase pertumbuhan vegetatif perlu diberikan pupuk dengan kandungan $\mathrm{N}$ yang tinggi, karena unsur tersebut merupakan bahan utama untuk menyusun protein yang dibutuhkan dalam pembelahan sel (Sandra, 2001). Pada tanaman anggrek muda pemberian pupuk dengan kandungan N tinggi akan memberikan pertumbuhan yang lebih baik dan cepat, karena nitrogen adalah bahan utama penyusun asam amino, protein, asam nukleat, berbagai enzim dan sebagai zat penghijau daun.

Secara keseluruhan hasil penelitin menunjukkan bahwa anggrek dendrobium dapat hidup dan tumbuh dengan baik pada media pakis, arang, kulit pohon kelapa, kulit pohon akasia dan serbuk gergaji + sekam dengan diberi pupuk daun Gandasil atau Hyponex . 
Tri Dewi Andalasari, Yafisham, dan Nuraini: Respon Pertumbuhan Anggrek Dendrobium ...

\section{KESIMPULAN}

Penggunaan media tanam arang, serbuk gergaji + sekam, kulit pohon akasia, kulit pohon kelapa dapat digunakan sebagai media tanam anggek sama seperti media pakis. Penggunaan pupuk Gandasil lebih baik daripada pupuk Hyponex. Penggunaan pupuk daun tidak tergantung kepada penggunaan jenis media tanam.

\section{SARAN}

Disarankan untuk menggunakan media media alternatif pengganti pakis dan arang kayu dengan media tanam serbuk kayu + sekam, kulit pohon akasia dan kulit pohon kelapa yang merupakan limbah usaha pengolahan kayu.

\section{DAFTAR PUSTAKA}

Benamehuli Ginting. 2008. Media Tanam Anggrek. KP Penelitian Tanaman Hias, Departemen Pertanian. Dimuat pada surat kabar Sinar Tani, 7 - 13 Mei 2008

Direktorat Jenderal Hortikultura. 2008. Statistik Produksi Tanaman Hias di Indonesia 2003-2007. Dalamhttp://www.hortikultura.deptan.go.id/index..php?=comcontent\&task View\&id=124\&itemed=160. Diakses tanggal 22 April 2009.

Don,WS., Threes Emir dan Cherry Hadibroto, 2001. Cara Menanam dan Merawat Anggrek Bulan. PT. Gramedia Pustaka Utama. Jakarta. 48 hlm.

Ginting B., W. Prasetio dan T. Sutater.2004 Media Tumbuh untuk Varietas Baru Anggrek Dendrobium. Prosiding Seminar Nasional Florikultura, Bogor, 4-5 Agustus.65-70

Gunawan Livy W. 2000. Budidaya Anggrek. Penebar Swadaya. Jakarta. 86 hlm

Iswanto Hadi. 2002. Petunjuk Perawatan Anggrek. Agromedia Pustaka. Jakarta. 65 hlm.

John, G. Dan Jim L. Bowyer. 1986. Hasil Hutan dan Ilmu Kayu: Suatu Pengantar. University Press. Yogjakarta. $719 \mathrm{hlm}$.

Lingga, Pinus dan Marsono. 2001. Petunjuk Penggunaan Pupuk. Penebar Swadaya. Jakarta. 150 hlm

PT Kalatham (Distributor Pupuk Gandasil). Pupuk Daun yang Lengkap dan Sempurna. Leaflet. Jakarta. $1 \mathrm{hlm}$.

PT Paramanira (Distributor Pupuk Hyponex). Penunjang Sarana Pertamanan dan Pertanian Yang Efektif Hyponex. Leaflet. Jakarta. $1 \mathrm{hlm}$.

Rukmana, Rahmat. 2000. Budidaya Anggrek Bulan. Kanisius. Yogyakarta. 76 hlm

Salisbury, Frank B., dan Cleon w Ross. 1992. Fisiologi Tumbuhan. Jilid II: Biokimia Tumbuhan. ITB Bandung. $173 \mathrm{hlm}$. 
Santina, Laurensia. 1990. Pengaruh Media Terhadap Pertumbuhan Anggrek Dendrobium Hibrida yang Ditumbuhkan pada Batang Pinus Merkussi. Skripsi Sarjana Pertanian. Universitas Lampung. $55 \mathrm{hlm}$.

Sandra, Edhi. 2001. Membuat Anggrek Rajin Berbunga. Agromedia Pustaka. Jakarta. 54 hlm

Sri Wardani, Hot Setiado, dan Syarifuddin Ilyas. 2011. Pengaruh Media Tanam dan Pupuk Daun terhadap Aklimatisasi Anggrek Dendrobium (Dendrobium sp). Jurnal Pertanian Kultivar. Vol 5 No 1 2011. Diakses 18 Nov 2013.

Supari, DH. 1999. Tuntunan Membangun Agribisnis (Seri Praktek Ciputri Hijau). PT Alex Media Komputindo. $422 \mathrm{hlm}$.

Sutiyoso, Yos dan B Sarwono. 2003. Merawat Anggrek. Penebar Swadaya. Jakarta . 72 hlm.

Tangti Yosepa, Chairani Siregar, Evi Gusmayanti, 2013. Pengaruh Penggunaan Jenis Media Terhadap Aklimatisasi Anggrek Dendrobium Sp(Hibrida). Jurnal Sain Mahasiswa Pertanian Universitas Tanjungpura. Vol 2 No 2. Agstus 2013. Diakses 18 Nov 2013.

Widiastoety, Dyah. 2004. Bertanam Anggrek. Penebar Swadaya. Jakarta. 76 hlm. 